\title{
Preliminary in vitro screening of the antibacterial activity of leaf extracts from various Ficus species (Moraceae) against Yersinia ruckeri
}

\author{
Halyna Tkachenko, Lyudmyla Buyun, Elżbieta Terech-Majewska, Vitaliy Honcharenko, \\ Andriy Prokopiv, Zbigniew Osadowski
}

Received - 30 October 2018/Accepted - 07 March 2019. Published online: 31 March 2019; @Inland Fisheries Institute in Olsztyn, Poland Citation: Tkachenko H., Buyun L., Terech-Majewska E., Honcharenko V., Prokopiv A., Osadowski Z. 2019 - Preliminary in vitro screening of the antibacterial activity of leaf extracts from various Ficus species (Moraceae) against Yersinia ruckeri - Fish. Aquat. Life 27: 15-26.

\begin{abstract}
Remarkable progress in the field of antibacterial herbal therapy has been made in recent decades in response to the development of drug-resistant pathogens in aquaculture. Studies have focused on the in vitro antimicrobial activity screening of ethanolic extracts of various plants belonging to the genus Ficus. The aim of the present study was to evaluate the antibacterial efficacy of ethanolic extracts of various Ficus species against Yersinia ruckeri. In vitro tests for antibacterial activity revealed that ethanolic leaf extracts of various Ficus species and their cultivars offer a promising alternative to antibiotics and chemotherapeutics for controlling the growth of Y. ruckeri. In our study, ethanolic extracts obtained from leaves
\end{abstract}

\footnotetext{
H. Tkachenko [ $\left.\Xi^{\circ}\right]$, Z. Osadowski

Institute of Biology and Environmental Protection,

Pomeranian University in Słupsk

ul. Arciszewskiego 22B, 76-200 Słupsk, Poland

e-mail: halyna.tkachenko@apsl.edu.pl

\section{Buyun}

M.M. Gryshko National Botanic Garden, National Academy of

Science of Ukraine, Kyiv, Ukraine

E. Terech-Majewska

Department of Epizootiology, University of Warmia and Mazury in

Olsztyn, Poland

V. Honcharenko, A. Prokopiv

Ivan Franko Lviv National University, Lviv, Ukraine

A. Prokopiv
Botanic Garden of Ivan Franko Lviv National University, Lviv, Ukraine
}

of $F$. natalensis subsp. leprieurii and F. macrophylla proved effective against a bacterial strain at a dose of $400 \mu \mathrm{l}$ standardized inoculum $\left(10^{8} \mathrm{CFU} \mathrm{ml}^{-1}\right)$. It should be noted that $Y$. ruckeri demonstrated an intermediate susceptibility to more extracts derived from the leaves of Ficus species. Our investigation showed that among the various Ficus species, ethanolic leaf extracts of ten Ficus species against Y. ruckeri were the most effective. The effect of the leaf extracts that expressed the highest antimicrobial activity ( $F$. macrophylla, $F$. natalensis subsp. leprieurii) against $Y$. ruckeri was comparable to that of gentamicin. Therefore, preliminary screening indicated that the ethanolic leaf extracts of some Ficus species with antibacterial properties can be used in aquaculture as therapeutic and prophylactic agents against fish pathogens, including Y. ruckeri.

Keywords: antibacterial activity, Kirby-Bauer disk diffusion technique, ethanolic extracts, fish pathogens, susceptibility, resistance

\section{Introduction}

Yersinia ruckeri is a ubiquitous pathogen of finfish capable of causing major mortalities in farmed fish stocks (Ghosh et al. 2016). This bacterium is an etiological agent of enteric redmouth disease (ERM) of farmed salmonids (Ormsby et al. 2016). The 
causative agent, a Gram-negative enteric bacterium, which was first isolated in the Hagerman Valley, Idaho, USA, in the early 1950s, is described fully by Ross et al. (1966), and it was identified as the new species, Y. ruckeri, in 1978 (Ewing et al. 1978). Y. ruckeri is a member of the family Enterobacteriaceae within the gamma-proteobacteria subdivision. Generally of coccoid-rod cell morphology, Y. ruckeri cells are slightly curved, $1.0 \mu \mathrm{m}$ in diameter, and $2-3 \mu \mathrm{m}$ in length, although culture for $48 \mathrm{~h}$ or longer results in long filamentous cells (Barnes 2011). Y. ruckeri has a wide host range, a broad geographical distribution, and causes significant economic losses in the fish aquaculture industry (Kumar et al. 2015).

Y. ruckeri can be transmitted vertically from parent to progeny as well as horizontally in the water column from both clinically infected fish and asymptomatic carriers and is consequently capable of infecting fish at early stages of development (Ghosh et al. 2016). The disease takes its name from the subcutaneous hemorrhages it can cause at the corners of the mouth and in the gums and tongue. Other clinical signs include exophthalmia, darkening of the skin, splenomegaly, and inflammation of the lower intestine with an accumulation of thick yellow fluid. The bacterium enters the fish through the secondary gill lamellae and from there it spreads to the blood and internal organs (Kumar et al. 2015). Infected fish and asymptomatic carriers are the main sources of infection, and the bacteria are spread by feces. Gills are regarded as the entry route of $Y$. ruckeri rods, but the likelihood of the disease depends on the virulence of a given strain. Characteristic clinical signs of yersiniosis, such as hemorrhages around the oral cavity, are caused by extracellular products of $Y$. ruckeri (Pękala and Antychowicz 2010). Antibiotics are frequently used in aquaculture to prevent the occurrence and to control these pathogens (Romero et al. 2012, Caruso 2016).

Antibiotic resistance has prompted research into developing novel strategies that can prevent bacterial growth (Abouzeed et al. 2013, Khameneh et al. 2015). Growing numbers of studies are focusing on identifying alternatives to antibiotics with similar antimicrobial and growth-promoting effects without inducing bacterial resistance and potential side effects to animals (Romero et al. 2012, Yang et al. 2015). Natural products from higher plants have traditionally been regarded as important sources of antimicrobial agents and have attracted extensive attention in fundamental research and clinic applications (Cheng et al. 2014). Numerous scientific reports have shown that plants have a high potential to synthesize different antimicrobial substances that play multiple essential roles in plant physiology and act as plant defense mechanisms and protect them against abiotic (UV radiation, drought, high or low temperatures, excessive soil salinity) and biotic stresses (i.e., microorganisms, insects, and herbivores) (Daglia 2012, Nabavi et al. 2015). It is assumed that phytogenic compounds play an important role in mediating interactions between plants and the environment (Yang et al. 2015). Natural products, especially those obtained from plants (phenolics and polyphenolics, terpenoids, alkaloids, lectins, polypeptides, and polyacetylenes), have proven to be outstanding compounds with unique properties, making them perfect candidates for these much-needed therapeutics (Borges et al. 2016). These secondary metabolites have potentially healthy properties for the human body mainly as antioxidants and anti-allergen, anti-inflammatory, anticancer, antihypertensive, and antimicrobial agents (Daglia 2012). The search for the healing potential of natural products is an idea from ancient times that is once again being pursued (Nabavi et al. 2015).

In addition to their medicinal use in humans, medicinal plants are used as chemotherapeutics and food additives in aquaculture because of their ability to enhance fish immune systems (Van Hai 2015). Currently, herbs are used widely in commercial aquaculture as growth-promoting substances, antibiotics, antimicrobial agents, nutrient sources, etc. Many herbal medicines have been found to be effective against fish pathogens (Birinci Yıldırım and 2018). Some studies report on the antimicrobial activities of essential oils on aquatic animal diseases (Al Laham et al. 2014). Treatments with medicinal plants that have antibacterial properties is a potentially beneficial alternative in aquaculture (Madhuri et al. 2012, Turker and Yıldirım 2015, Birinci 
Y1ldırım and Turker 2018). Phytogenic feed additives offer one way of improving fish health. Therefore, it is reasonable to assume that natural plant products can be a valuable source of antibacterial properties against multi-drug-resistant pathogens, including in aquaculture.

Botanical gardens play a fundamental role in the ex-situ conservation and exploration of global plant biodiversity (Cibrian-Jaramillo et al. 2013). Thus, it is assumed that living collections of tropical plants maintained in botanical gardens are an underutilized worldwide resource both for biodiversity conservation and practical uses. Therefore, given that many groups of plants are valuable sources of diverse compounds, possessing a broad spectrum of biological activity, the inter-institutional project between the Institute of Biology and Environmental Protection, Pomeranian University in Słupsk (Poland) and two botanical gardens in Ukraine, has recently begun assessing unexploited properties of various plant species derived from tropical biomass, and of Ficus species plants in particular (Tkachenko et al. 2016).

The genus Ficus L. (Moraceae), one of the most species-rich and ecologically important plant genera in lowland tropical rainforests, was chosen for an evaluation of antimicrobial activity, in particular, that of leaf extracts. In preparation for this study, ethnobotanical literature was reviewed regarding the traditional medicinal uses of various species of this large genus (Ali and Chaudhary 2011, Majumder and Paridhavi 2013).

Along with being an object of extreme interest for researchers over the last two centuries, Ficus has a long history of use by humans as a food source, in medicine, planting, and other industries and fields of human activity, partly owing to its great diversity and wide distribution range. Popular ethnomedicinal uses of Ficus include treatments of skin damage, disorders of the digestive system and related organs, and parasitic infections. In addition, the range of healing targets of particular Ficus species compiled from local medicines can be competitive with that of broad-spectrum traditional remedies (Lansky and Paavilainen 2011). A number of Ficus species are used as food and for medicinal properties in
Ayurvedic and traditional Chinese medicine especially by the people inhabiting areas where these species grow. They are used widely to treat various diseases. Recent pharmacological investigations have reported diverse medicinal properties of the plants belonging to the genus Ficus, e.g., anti-diabetic, cognitive enhancer, wound healing, anticonvulsant, anti-inflammatory, analgesic, antimicrobial, antiviral, hypolipidemic, antioxidant, immunomodulatory, anti-asthmatic, parasympathetic modulatory, estrogenic, antitumor, anti-ulcer, antianxiety, antihelminthic, endothelin receptor antagonistic, apoptosis inducer, and hypotensive activity, which have been validated in numerous scientific studies on various species of Ficus genus (Dangarembizi et al. 2012, Salem et al. 2013, Badgujar et al. 2014, Bunawan et al. 2014).

However, although many species within the genus Ficus have been the subjects of phytochemical and pharmacological investigations, there are many species that have not yet been studied and whose ethnobotanical relevance has yet to be investigated. Consequently, an attempt was made to study the in vitro antimicrobial activity of ethanolic extracts of various plants belonging to the genus Ficus. Several important Ficus species were chosen for an evaluation of their antimicrobial efficacy against locally isolated $Y$. ruckeri. Therefore, the aim of the present study was to evaluate the antibacterial efficacy of ethanolic extracts of various plants belonging to the genus Ficus against $Y$. ruckeri in order to validate scientifically the inhibitory activity attributed to their common use and to propose new sources of antimicrobial agents in aquaculture for the prevention and treatment of disease caused by these bacteria.

\section{Materials and methods}

\section{Collection of plant material and plant extract preparation}

The leaves of $F$. aspera G. Forst; $F$. benghalensis L.; $F$. benjamina L.; $F$. benjamina "Reginald"; $F$. 
binnendijkii (Miq.) Miq.; F. binnendijkii "Amstel Gold”; F. binnendijkii “Amstel King”; F. carica L.; F. craterostoma Warb. ex Mildbr. \& Burret; F. cyathistipula Warb.; F. deltoidea Jack; F. drupacea Thunb.; F. elastica Roxb.; F. elastica "Variegata"; F. erecta Thunb.; F. hispida L.f.; F. luschnathiana (Miq.) Miq.; F. lyrata Warb.; F. macrophylla Desf. ex Pers.; F. mucuso Welw. ex Ficalho; F. natalensis Hochst; F. natalensis Hochst. subsp. leprieurii (Miq.) C.C. Berg; F. palmeri S.Watson; F. platypoda (Miq.) A. Cunn. ex Miq.; F. pumila L.; F. religiosa L.; F. rubiginosa Desf. ex Vent.; F. sagittata Vahl; F. septica Burm. f.; F. sur Forssk.; F. sycomorus L.; F. vasta Forssk.; and F. villosa Blume were sampled at the M. M. Gryshko National Botanical Garden (NBG, Kyiv, Ukraine) and the Botanical Garden of Ivan Franko Lviv National University (Lviv, Ukraine). The entire collections of tropical and subtropical plants at both the NBG and the Botanical Garden of Ivan Franko Lviv National University, including the Ficus spp. plants, have the status of the National Heritage Collection of Ukraine. The species author abbreviations were taken from Brummitt and Powell (1992). It is well known that the lack of the standardization of species names can result in mismatched observations leading to erroneous scientific conclusions (Bortolus, 2008). Therefore, in our investigation close attention was paid to the correct identification of plant species names and the appropriate use of botanical nomenclature. The taxonomic identification of the Ficus plant species that were used in the investigation was confirmed by Sosnovskiy (2014). The authors of this paper used the authoritative digitized global taxonomy source of plant names.

Leaves sampled from various Ficus species were brought into the laboratory for antimicrobial studies. Freshly crushed leaves were washed, weighed, and homogenized in 96\% ethanol (in proportions of 1:10, $\mathrm{w} / \mathrm{w}$ ) at room temperature, and centrifuged at 3,000 $\mathrm{g}$ for 5 minutes. Supernatants were stored at $-20^{\circ} \mathrm{C}$ in bottles protected with laminated paper until analyses.

\section{Methods for culturing pathological samples and for identifying the $Y$. ruckeri strain}

The Y. ruckeri strain was collected from clinically healthy fish and fish with clinical symptoms of yersiniosis. Internal tissues (predominantly pronephros and gills) and intestinal swabs were sampled. Tissue samples were homogenized and inoculated on nutritional agar with 5\% blood (Columbia Blood Agar, Oxoid ${ }^{\circledR}$ ). Following a $24 \mathrm{~h}$ incubation period at $25 \pm 2{ }^{\circ} \mathrm{C}$, distinctive colonies were transferred onto TSA. Round, elevated, shining, and whitish colonies without hemolytic properties were considered typical of $Y$. ruckeri. After 24 h-incubation at $25 \pm 2{ }^{\circ} \mathrm{C}$, an oxidase test and Gram-staining were performed. Gram-negative and oxidase-negative isolates were cultured on TSA medium and incubated for $24 \mathrm{~h}$ at $25 \pm 2^{\circ} \mathrm{C}$. The strain was obtained from the Diagnostics Laboratory of Fish and Crayfish Diseases, Department of Veterinary Hygiene, Provincial Veterinary Inspectorate in Olsztyn (Poland).

The Y. ruckeri strain used for the study was initially identified using the morphological assessment and staining method (Gram-stained and then morphologically evaluated) (Kocwowa 1981, Whitman and MacNair 2004). Oxidase activity was determined for biochemical identification (Oxidase test, Merck Inc.) and the API 20E system (BioMérieux, France). Tests were performed according to the manufacturer's instructions. The Y. ruckeri strain according to API test 4104100 showed no movement.

\section{Bacterial growth inhibition test of plant extracts by the disk diffusion method}

The strain tested was plated on TSA medium (Tryptone Soy Agar) and incubated for $24 \mathrm{~h}$ at $25^{\circ} \mathrm{C}$. Subsequently, the microorganisms were suspended in sterile PBS, and the turbidity was adjusted equivalent to that of the $0.5 \mathrm{McF}$ arland standard. The antimicrobial susceptibility testing was done on Muller-Hinton agar with the disc diffusion method (Kirby-Bauer disk diffusion susceptibility test protocol) (Bauer et al. 1966). Muller-Hinton agar plates 
were inoculated with 200 and $400 \mu \mathrm{l}$ standardized inoculum $\left(10^{8} \mathrm{CFU} \mathrm{ml}{ }^{-1}\right)$ of the bacterium and spread with sterile swabs.

Sterile $6 \mathrm{~mm}$ filter paper discs with the plant extracts $(200 \mu \mathrm{l})$ were applied over each of the inoculated plates, $15 \mathrm{~min}$ after the bacterial suspension was placed on them. A negative control disc impregnated with sterile ethanol was used in each experiment. The sensitivity of the strain to a commercial preparation with garlic extracts was also studied (Alligastran, BIOfaktor, Poland) at dilutions of 1:10, 1:100, and 1:1000. The $Y$. ruckeri isolates were individually tested against four antibiotics, as follows: oxytetracycline $(30 \mu \mathrm{g})$; enrofloxacin $(5 \mu \mathrm{g})$; gentamicin $(10 \mu \mathrm{g})$; sulphamethoxazole/trimethoprim $(25 \mu \mathrm{g})$.

The plates were incubated at $25^{\circ} \mathrm{C}$ for $24 \mathrm{hrs}$. Antibacterial activities were evaluated by measuring the diameters of inhibition zones in mm against the test organism and compared with those of the control and standard susceptibility disks. Activity was evidenced by the presence of an inhibition zone surrounding the paper discs. The plates were then observed for the inhibition zone produced by the antibacterial activity of various ethanolic extracts obtained from leaves of Ficus species. At the end of the period, the inhibition zones formed were measured in mm using a vernier. Six replicates were assayed for each extract. The plates were examined and photographs were taken. Zone diameters were determined and averaged.

\section{Statistical analysis}

Statistical analysis of the data obtained was performed by employing the mean \pm standard error of the mean (S.E.M.). All variables were randomized according to the phytochemical activity of the extracts tested. The following zone diameter criteria were used to assign susceptibility or resistance of bacteria to the phytochemicals tested: Susceptible $(\mathrm{S}) \geq 15$ $\mathrm{mm}$, Intermediate (I) $=10-15 \mathrm{~mm}$, and Resistant (R) $\leq 10 \mathrm{~mm}$ (Okoth et al. 2013).

\section{Results}

The data of the screening study of antimicrobial activity of ethanolic leaf extracts obtained from various Ficus species plants against the Y. ruckeri strain (plates with 200 and $400 \mu \mathrm{l}$ standardized inoculum) are presented in Tables 1 and 2 and in Figs. 1 and 2 . The comparison of susceptibility categories, i.e., high and intermediate susceptibility and resistant, for the disk diffusion technique is shown in Tables 1 and 2 . Our results demonstrated that the $Y$. ruckeri strain (200 $\mu \mathrm{L}$ standardized inoculum) revealed

\section{Table 1}

Inhibition zone diameters (IZD) of $Y$. ruckeri growth $(200 \mu \mathrm{L}$ inoculum) induced by leaf ethanolic extracts obtained from various Ficus species $(\mathrm{n}=6)$

\begin{tabular}{lc}
\hline \hline & Inhibition zone \\
Ficus species & diameters $(\mathrm{mm})$ \\
\hline \hline Intermediate susceptibility, IZD $=10-15 \mathrm{~mm}$ \\
F. benjamina & $12.25 \pm 0.73$ \\
F. deltoidea & $12.17 \pm 0.95$ \\
F. erecta & $14.25 \pm 0.48$ \\
F. hispida & $13.67 \pm 0.49$ \\
F. lyrata & $11.67 \pm 0.61$ \\
F. macrophylla & $12.17 \pm 0.95$ \\
F. natalensis subsp. leprieurii & $13.08 \pm 0.90$ \\
F. natalensis & $14.17 \pm 0.31$ \\
F. palmeri & $14.08 \pm 0.66$ \\
F. platypoda & $11.67 \pm 0.56$ \\
F. pumila & $12.67 \pm 0.71$ \\
F. sagittata & $14.33 \pm 1.23$ \\
F. sycomorus & $13.83 \pm 0.79$ \\
Resistant, IZD $\leq 10$ mm & \\
F. aspera & $8.58 \pm 0.33$ \\
F. benghalensis & $8.83 \pm 0.33$ \\
F. benjamina 'Reginald' & $8.83 \pm 0.34$ \\
F. binnendijkii & $8.75 \pm 0.31$ \\
F. binnendijkii 'Amstel Gold' & $8.58 \pm 0.33$ \\
F. binnendijkii 'Amstel King' & $8.92 \pm 0.45$ \\
F. carica & $9.25 \pm 0.38$ \\
F. craterostoma & $8.92 \pm 0.37$ \\
F. cyathistipula & $8.50 \pm 0.26$ \\
F. drupacea & $8.58 \pm 0.51$ \\
F. elastica & $8.42 \pm 0.20$ \\
F. elastica 'Variegata' & $8.92 \pm 0.27$ \\
F. luschnathiana & $8.75 \pm 0.50$ \\
F. mucuso & $8.92 \pm 0.27$ \\
F. religiosa & $8.83 \pm 0.38$ \\
F. rubiginosa & $8.50 \pm 0.43$ \\
F. septica & $8.75 \pm 0.31$ \\
F. sur & $8.50 \pm 0.34$ \\
F. vasta & $8.75 \pm 0.50$ \\
F. villosa & $8.83 \pm 0.28$ \\
\hline \hline
\end{tabular}


Table 2

Inhibition zone diameters (IZD) of Y. ruckeri growth $(400 \mu \mathrm{L}$ inoculum) induced by leaf ethanolic extracts obtained from various Ficus species $(\mathrm{n}=6)$

\begin{tabular}{|c|c|}
\hline Ficus species & $\begin{array}{l}\text { Inhibition zone } \\
\text { diameters (mm) }\end{array}$ \\
\hline \multicolumn{2}{|l|}{ "High susceptibility, IZD > $15 \mathrm{~mm}$} \\
\hline F. macrophylla & $15.33 \pm 0.76$ \\
\hline F. natalensis subsp. leprieurii & $15.50 \pm 0.43$ \\
\hline \multicolumn{2}{|c|}{ Intermediate susceptibility, IZD = $10-15 \mathrm{~mm}$} \\
\hline F. benghalensis & $13.17 \pm 0.79$ \\
\hline F. benjamina & $12.50 \pm 0.76$ \\
\hline F. benjamina 'Reginald' & $12.75 \pm 0.72$ \\
\hline F. binnendijkii & $13.25 \pm 0.48$ \\
\hline F. binnendijkii 'Amstel King' & $11.67 \pm 0.79$ \\
\hline F. cyathistipula & $13.75 \pm 0.31$ \\
\hline F. drupacea & $14.42 \pm 0.66$ \\
\hline F. elastica & $12.67 \pm 0.67$ \\
\hline F. erecta & $12.50 \pm 0.76$ \\
\hline F. luschnathiana & $12.50 \pm 0.76$ \\
\hline F. palmeri & $11.75 \pm 0.44$ \\
\hline F. pumila & $14.83 \pm 0.95$ \\
\hline F. religiosa & $13.42 \pm 0.37$ \\
\hline F. sagittata & $11.33 \pm 0.44$ \\
\hline F. septica & $12.50 \pm 0.76$ \\
\hline \multicolumn{2}{|l|}{ Resistant, $\mathrm{IZD} \leq 10 \mathrm{~mm}$} \\
\hline F. aspera & $8.50 \pm 0.50$ \\
\hline F. binnendijkii 'Amstel Gold' & $8.17 \pm 0.31$ \\
\hline F. carica & $8.5 \pm 0.50$ \\
\hline F. craterostoma & $8.51 \pm 0.34$ \\
\hline F. deltoidea & $8.75 \pm 0.31$ \\
\hline F. elastica 'Variegata' & $8.75 \pm 0.36$ \\
\hline F. hispida & $8.72 \pm 0.31$ \\
\hline F. lyrata & $8.92 \pm 0.37$ \\
\hline F. mucuso & $8.25 \pm 0.40$ \\
\hline F. natalensis & $8.83 \pm 0.65$ \\
\hline F. platypoda & $8.92 \pm 0.66$ \\
\hline F. rubiginosa & $8.50 \pm 0.45$ \\
\hline F. sur & $8.42 \pm 0.20$ \\
\hline F. sycomorus & $8.58 \pm 0.21$ \\
\hline F. vasta & $8.50 \pm 0.34$ \\
\hline F. villosa & $8.58 \pm 0.42$ \\
\hline
\end{tabular}

intermediate susceptibility (according to the inhibition zone diameter) to the ethanolic extracts derived from F. benjamina, F. deltoidea, F. erecta, F. hispida, $F$. lyrata, F. macrophylla, F. natalensis subsp. leprieurii, $F$. natalensis, $F$. palmeri, $F$. platypoda, $F$. pumila, $F$. sagittata, and $F$. sycomorus (the mean of inhibition zone diameters ranged from 10 to $15 \mathrm{~mm}$ ). The highest value of inhibition zone diameter was noted for F. sagittata $(14.33 \pm 1.23 \mathrm{~mm}), F$. erecta $(14.25 \pm 0.48 \mathrm{~mm}), F$. natalensis $(14.17 \pm 0.31 \mathrm{~mm})$, and F. palmeri $(14.08 \pm 0.66 \mathrm{~mm})$. On the other hand, the Y. ruckeri strain was resistant to ethanolic extracts obtained from the leaves of $F$. aspera, $F$. benghalensis, $F$. benjamina "Reginald," $F$. binnendijkii and its cultivars ("Amstel Gold," "Amstel King”), F. carica, F. craterostoma, F. cyathistipula, F. drupacea, F. elastica, F. elastica "Variegata," F. luschnathiana, F. mucuso, $F$. religiosa, F. rubiginosa, F. septica, F. sur, F. vasta, and $F$. villosa (the mean inhibition zone diameters were less than $10 \mathrm{~mm}$; Table 1).

The Y. ruckeri strain applied to the plates in doses of $400 \mu \mathrm{l}$ standardized inoculum revealed a high level of susceptibility to ethanolic extracts obtained from the leaves of $F$. natalensis subsp. leprieurii and $F$. macrophylla (the mean values of inhibition zone diameters were $15.50 \pm 0.43 \mathrm{~mm}$ and $15.33 \pm 0.76$ $\mathrm{mm}$, respectively; Table 2). Moreover, high inhibition zone diameter values were noted for $F$. pumila (14.83 $\pm 0.95 \mathrm{~mm})$ and $F$. drupacea $(14.42 \pm 0.66 \mathrm{~mm})$ from a group of Ficus species with intermediate susceptibility against $Y$. ruckeri. The inhibition zone diameters for F. aspera, F. binnendijkii “Amstel Gold,” F. carica, F. craterostoma, F. deltoidea, F. elastica "Variegata," $F$. hispida, F. lyrata, $F$. mucuso, $F$. natalensis, $F$. platypoda, F. rubiginosa, F. sur, F. sycomorus, F. vasta, and $F$. villosa were in a range of less than $10 \mathrm{~mm}$ (Table 2). Data on the antimicrobial activity of ethanolic extracts obtained from F. religiosa, F. cyathistipula, F. lyrata, $F$. benghalensis, and $F$. binnendijkii against the $Y$. ruckeri strain applied to the plates in doses of 200 and $400 \mu \mathrm{l}$ standardized inoculum and Y. ruckeri strain susceptibility against oxytetracycline $(30 \mu \mathrm{g})$, enrofloxacin (5 $\mu \mathrm{g})$, gentamicin $(10 \mu \mathrm{g})$, and sulphamethoxazole/trimethoprim $(25 \mu \mathrm{g})$ are presented in Figs. 1 and 2.

As is evident from Fig. 2, the Y. ruckeri strain was found susceptible to the antibiotics studied. Specifically, our results also revealed that the Y. ruckeri strain applied to plates in doses of $200 \mu \mathrm{l}$ exhibited a high level of susceptibility to enrofloxacin (the inhibition zone diameter was $40.5 \pm 0.62 \mathrm{~mm}$ ), sulphamethoxazole $(30.0 \pm 0.58 \mathrm{~mm})$, oxytetracycline $(25.17 \pm 0.40 \mathrm{~mm})$, and gentamicin $(15.0 \pm$ $0.26 \mathrm{~mm}$ ) (Fig. 2A). On plates with the Y. ruckeri 

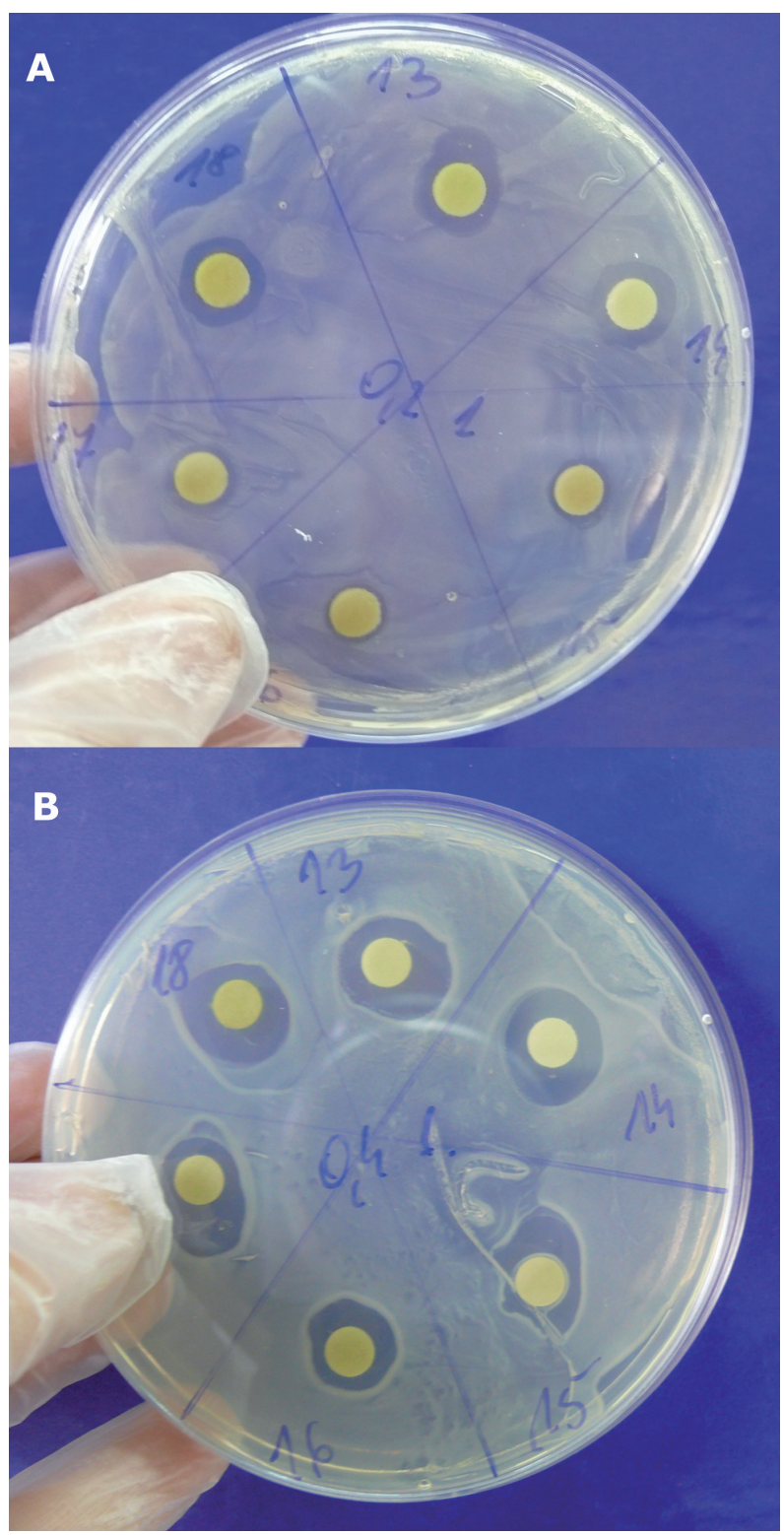

Figure 1. Antimicrobial activity of ethanolic extracts obtained from $F$. religiosa (13), F. cyathistipula (14), F. lyrata (15), F. benghalensis $(16,17)$, and $F$. binnendijkii (18) against the $Y$. ruckeri strain applied to plates in doses of $200 \mu \mathrm{L}$ (A) and $400 \mu \mathrm{L}$ standardized inoculum (B).

strain applied in doses of $400 \mu \mathrm{l}$, the inhibition zone diameters were $35.5 \pm 0.43 \mathrm{~mm}$ for enrofloxacin, $30.17 \pm 0.54 \mathrm{~mm}$ for sulphamethoxazole, $25.0 \pm 0.58 \mathrm{~mm}$ for oxytetracycline, and $21.33 \pm$ $0.80 \mathrm{~mm}$ for gentamicin (Fig. 2B). The largest inhibition zones against the bacterial strain were observed in positive controls (reference antibiotics), while there was no inhibition zone in the negative control
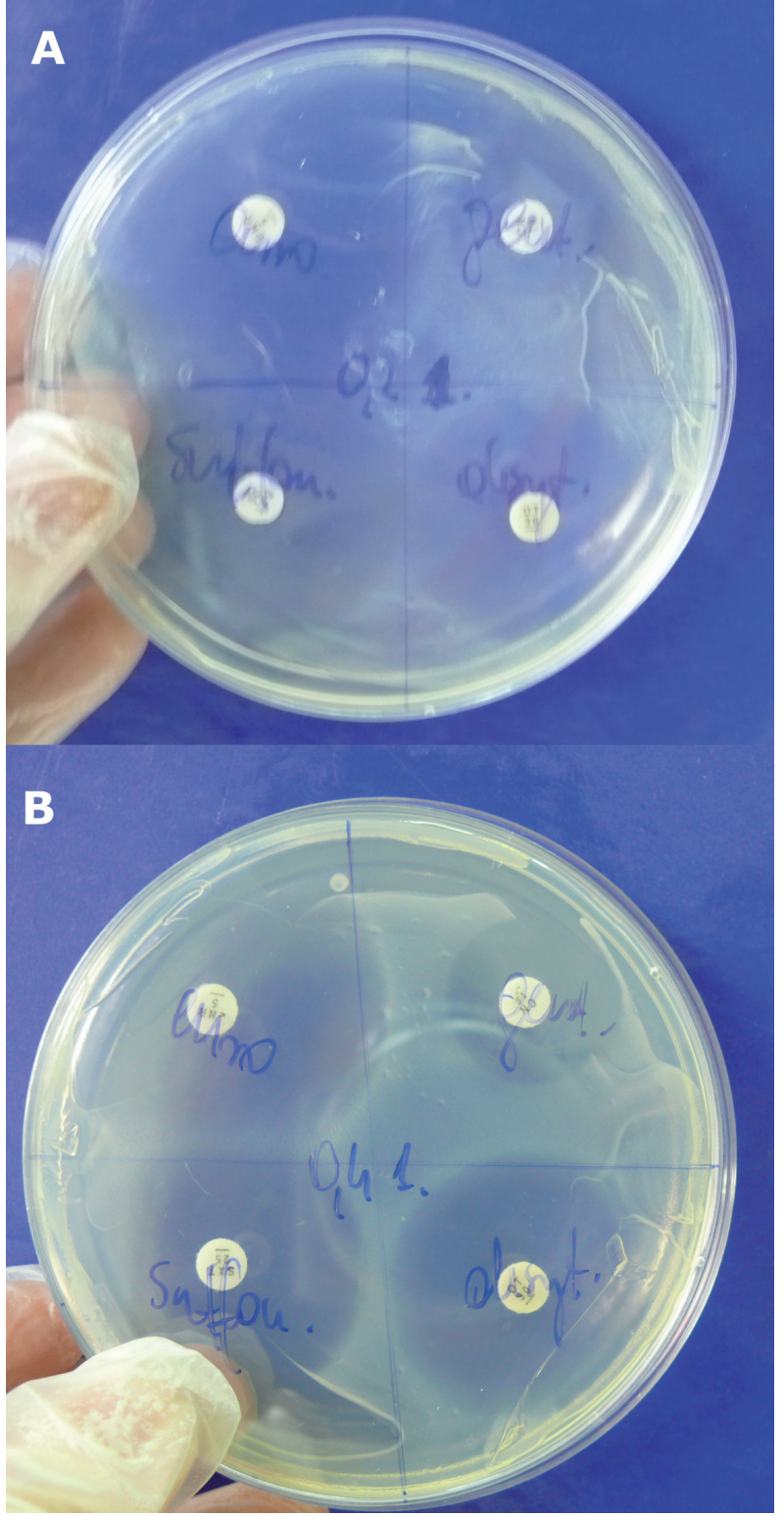

Figure 2. Susceptibility of the Y. ruckeri strain applied to plates in doses $200 \mu \mathrm{L}$ (A) and $400 \mu \mathrm{L}$ standardized inoculum (B) against oxytetracycline $(30 \mu \mathrm{g})$, enrofloxacin $(5 \mu \mathrm{g})$, gentamicin $(10 \mu \mathrm{g})$, and sulphamethoxazole/trimethoprim $(25 \mu \mathrm{g})$.

(ethanol and preparation with garlic extracts in dilutions of 1:10, 1:100, and 1:1000).

\section{Discussion}

Pursuant to the increased interest in the study of the antibacterial potential of different tropical plants, we 
examined the antibacterial efficacy of 35 extracts obtained from Ficus species and their cultivars against the fish pathogen Y. ruckeri. The results from the screening study performed by the disc diffusion technique are shown in Tables 1 and 2 and Fig. 1. These results showed that 22 of 35 plant extracts exhibited no activity against the $Y$. ruckeri strain $(200 \mu \mathrm{L}$ inoculum), specifically the ethanolic extracts of $F$. aspera, $F$. benghalensis, $F$. benjamina "Reginald," $F$. binnendijkii and its cultivars ("Amstel Gold," "Amstel King”), F. carica, F. craterostoma, F. cyathistipula, F. drupacea, F. elastica, F. elastica "Variegata," F. erecta, F. luschnathiana, F. mucuso, F. religiosa, $F$. rubiginosa, $F$. septica, F. sur, F. vasta, and $F$. villosa. The largest inhibition zones were noted for the ethanolic extracts of $F$. sagittata, $F$. erecta, $F$. natalensis, and $F$. palmeri. These extracts showed similar intermediate activity to that of gentamicin against $Y$. ruckeri (Table 1 ).

The extracts that showed the broadest antibacterial potential against $Y$. ruckeri applied in doses of $400 \mu \mathrm{l}$ standardized inoculum were the ethanolic extracts of $F$. natalensis subsp. leprieurii and $F$. macrophylla. Fifteen extracts showed intermediate activity against the bacterial strain tested in this study (F. benghalensis, $F$. benjamina, $F$. benjamina "Reginald," F. binnendijkii, F. binnendijkii "Amstel King," F. cyathistipula, F. drupacea, F. elastica, F. erecta, F. luschnathiana, F. palmeri, F. pumila, F. religiosa, $F$. sagittata, and $F$. septica). The weakest antibacterial activity was recorded for 16 species $(F$. aspera, F. binnendijkii “Amstel Gold," F. carica, F. craterostoma, F. deltoidea, F. elastica "Variegata," F. hispida, F. lyrata, F. mucuso, F. natalensis, F. platypoda, F. rubiginosa, F. sur, F. sycomorus, F. vasta, F. villosa) (Table 2).

This investigation concurs with our previous work that revealed the great potential of Ficus species as plants with potent antimicrobial properties. In our previous study, we evaluated the in vitro antimicrobial activity of ethanolic leaf extracts of various Ficus species against Aeromonas hydrophila, Citrobacter freundii, and Pseudomonas fluorescens (Tkachenko et al. 2016, 2017). Similarly to these general findings, there is copious evidence that various species of the genus Ficus possess antimicrobial activity against a broad spectrum of microorganisms. Ficus species have been the focus of increasing scientific interest in recent years. Consequently, it is well documented that various Ficus species have been used against Gram-positive and Gram-negative bacteria (Salem et al. 2013). For instance, Mousa et al. (1994) tested chloroform extract from the fruit of four Ficus species (F. benghalensis, $F$. benjamina, $F$. religiosa, and $F$. sycomorus) for antimicrobial activity against 22 pathogenic bacterial and fungal strains. The extracts had significant antibacterial activity but no antifungal activity. $F$. benjamina extracts were generally the most active against bacteria, while those of $F$. religiosa were the least active. The strain of $P$. aeruginosa HAMBI 25, which was generally weakly susceptible among the organisms tested, was weakly inhibited by $F$. benghalensis, F. benjamina, and $F$. sycomorus extracts (inhibition zone diameters of 16-19 mm) (Mousa et al. 1994).

Nair and Chanda (2006) have screened aqueous and ethanol extracts from 20 plant species, among which were four species of Ficus (F. benghalensis, $F$. racemosa, $F$. religiosa, and $F$. tisela), against seven Gram-negative (Pseudomonas aeruginosa ATCC27853, Pseudomonas testosteroni NCIM5098, Proteus mirabilis NCIM2241, Proteus vulgaris NCTC8313, Enterobacter aerogenes ATCC10240, Escherichia coli ATCC25922, and Citrobacter freundii ATCC10787) and five Gram-positive (Staphylococcus epidermidis ATCC12228, Bacillus cereus ATCC11778, Streptococcus fecalis ATCC29212, Streptococcus cremoris NCIM2179, and Streptococcus agalactiae NCIM2401) bacterial strains. Aqueous extracts generally showed less activity than ethanol extracts, and Gram-positive bacteria were generally more affected than Gram-negative ones. The Ficus species examined, of which bark extracts were used, showed low inhibition activity in general. Only their methanolic extracts affected $P$. aeruginos $a$ with a small inhibition zone diameter of 3 $\mathrm{mm}$ for F. tisela, $2.5 \mathrm{~mm}$ for $F$. racemosa, and $2 \mathrm{~mm}$ for F. benghalensis (Nair and Chanda 2006). 
Likewise, further studies (Nair and Chanda 2007) tested aqueous and ethanol extracts from ten Indian plant species, including the same species of Ficus (F. benghalensis, F. racemosa, F. religiosa, and F. tisela), against several medically important bacterial strains (Alcaligenes faecalis ATCC 8750, Bacillus cereus ATCC 11778, Pseudomonas aeruginosa ATCC 27853, Proteus mirabilis NCIM 2241, Salmonella typhimurium ATCC 23564, and Staphylococcus aureus ATCC 25923). The ethanol extracts were more potent than aqueous extracts of all the plants studied. Almost all Ficus bark extracts showed activity against each of the bacteria tested, although the strength of inhibition varied. $P$. aeruginosa was among the most resistant bacteria tested. Ficus species demonstrated low inhibition of $P$. aeruginosa, with inhibition zone diameters of $3 \mathrm{~mm}$ ( $F$. benghalensis and $F$. tisela ethanol extracts) and $2 \mathrm{~mm}$ (F. racemosa ethanol extract). Aqueous extracts of all Ficus species and both extracts of $F$. religios $a$ were inactive against $P$. aeruginosa (Nair and Chanda 2007).

Atindehou et al. (2002) tested crude ethanol extracts from 115 plant species against Gram-negative bacteria (E. coli and P. aeruginosa), Gram-positive bacteria (Enterococcus faecalis and Staphylococcus aureus), and fungi (Candida albicans and Cladosporium cucumerinum). Three Ficus species, namely $F$. exasperata, $F$. mucuso, and $F$. sur, were among the plants tested. The Gram-negative bacteria appeared unaffected by any plant extract tested, whereas the Gram-positive bacteria and fungi were inhibited by at least several plant species. Among the Ficus species tested, F. exasperata and F. mucuso had no significant effect on any of the microorganisms, while $F$. sur was one of the most active plant species against Gram-positive bacteria (Atindehou et al. 2002).

Similarly to the results of the present study, previous studies found that $F$. septica extract possessed moderate activity against bacteria and fungi and high effectiveness against protozoans. Vital et al. (2010) tested the leaf ethanol extract from F. septica Burm. and Sterculia foetida L. on a number of microorganisms such as bacteria (Bacillus cereus UPCC 1281, E. coli UPCC 1195, Pseudomonas aeruginosa UPCC
1244, and Staphylococcus aureus UPCC 1143), fungi (Candida albicans UPCC 2168), and protozoans (Entamoeba histolytica HK-9 and Trichomonas vaginalis DSHC 2021) with disc diffusion assays (for bacteria and fungi), growth curve determinations, and antiprotozoal and cytotoxicity assays (for protozoans). Their study showed moderate activity of both plant species extracts against bacteria and fungi and high effectiveness against protozoans. The extract from $F$. septica inhibited the growth of only E. coli and $S$. aureus among the bacteria tested, and its effectiveness was similar for both pathogens (inhibition zone diameter of 13.0 and $13.83 \mathrm{~mm}$, respectively. Although Vital et al. (2010) present results of phytochemical analysis, listing the chemical classes found (such as alkaloids, quaternary base, tannins, 2-deoxysugars, and benzopyrone nucleus), no suggestions or speculations are provided regarding any possible antimicrobial activities of particular chemicals.

Previous reports have demonstrated that the various Ficus species possess potent antimicrobial activity against pathogenic bacterial and fungal strains, and these effects can be explained due to the presence of secondary metabolites that are probably responsible for microorganism susceptibility to them. According to Salem et al. (2013), the phytochemical screening of leaves and stem bark extracts of various Ficus species revealed the presence of alkaloids, balsams, carbohydrates, flavonoids, free anthraquinones, tannins, glycosides, terpenes, resins, sterols, and saponins.

Numerous investigations have shown that plant extracts contain natural compounds, such as phenolic compounds, polysaccharides, proteoglycans, and flavonoids that are able to stimulate fish immune systems, and, therefore, they may play major roles in the prevention or control of infectious microbes (Reverter et al. 2014). The presence of alkaloids and flavonoids both reveals activity against pathogenic bacteria and suggests a role in the limitation of fungal infection, given that many flavonoids exhibit antifungal activity (Cushnie and Lamb 2005). Furthermore, it is interesting that antibacterial flavonoids might have multiple cellular targets, 
rather than one specific site of action. One of their molecular actions is to form complexes with proteins through nonspecific forces such as hydrogen bonding and hydrophobic effects, and by covalent bond formation (Cowan 1999). The B ring of the flavonoids may intercalate or form a hydrogen bond with the stacking of nucleic acid bases and further lead to inhibition of DNA and RNA synthesis in bacteria. Thus, their mode of antimicrobial action may be related to their ability to inactivate microbial adhesins, enzymes, cell envelope transport proteins, and so forth. Lipophilic flavonoids may also disrupt microbial membranes (Cowan 1999). Several flavonoids including apigenin, galangin, flavone and flavonol glycosides, isoflavones, flavanones, and chalcones have been shown to possess potent antibacterial activity (Cushnie and Lamb 2005). Among polyphenols, flavan-3-ols, flavonols, and tannins received the most attention because of their wide spectrum and higher antimicrobial activity in comparison with other polyphenols and because most of them are able to suppress a number of microbial virulence factors (such as the inhibition of biofilm formation, the reduction of host ligands adhesion, and the neutralization of bacterial toxins) and show synergism with antibiotics (Daglia 2012). Moreover, crude plant extracts are pharmacologically more active than their isolated active principles because of the synergistic effects of various components present in whole extracts (Padmanabhan et al. 2012).

Thus, both a review of the literature and the authors' own previous findings have shown that disease control in aquaculture is an active research field, and the application of plant extracts are promising alternatives to antibiotic treatments. Moreover, taking into account the numerous hazards to public health associated with the use of antimicrobials in aquaculture, e.g., the development and spread of antimicrobial-resistant bacteria, resistance genes, and the presence of antimicrobial residues in aquaculture products and the environment (Romero et al. 2012, Yang et al. 2015, Caruso 2016), such considerations make the search for plant-derived antimicrobial agents as eco-friendly alternatives to antibiotics especially urgent.

\section{Conclusions}

Our results revealed that the ethanolic leaf extracts of various Ficus species and their cultivars that were tested are promising alternatives to the use of antibiotics and chemotherapeutics in controlling Y. ruckeri growth. In our study, ethanolic extracts obtained from leaves of $F$. natalensis subsp. leprieurii and $F$. macrophylla proved effective against bacterial strains in doses of $400 \mu \mathrm{l}$ standardized inoculum $\left(10^{8} \mathrm{CFU}\right.$ $\mathrm{ml}^{-1}$ ) with mean inhibition zone diameters of 15.50 and $15.33 \mathrm{~mm}$, respectively. It should be noted that Y. ruckeri demonstrated intermediate susceptibility to more extracts derived from the leaves of Ficus species. Therefore, these results can be considered for further investigations aimed at identifying novel natural antimicrobial compounds in leaf extracts of some Ficus species that can be used in the aquaculture industry as therapeutic and prophylactic agents against fish pathogens, including Y. ruckeri.

Nevertheless, more extensive studies should be conducted prior to the development of novel antimicrobial pharmaceuticals based on Ficus species and their cultivars. The potential antimicrobial compounds comprising the extracts of various Ficus species tested should be isolated, purified, and examined further. Finally, the mechanisms of action of these potential active compounds should also be assessed. Further studies are needed to evaluate the effectiveness of the screened extracts and the potential impact of these substances on fish and on the environment.

Acknowledgments. The study was supported by a grant from the International Visegrad Fund, and we thank them for financial assistance for our study.

Author contributions. H.T. and L.B. performed the experiment, analyzed the data, and wrote the manuscript, E.T.-M. performed the disk diffusion method, V.H., A.P., and Z.O. analyzed the data. 


\section{References}

Abouzeed Y.M., Elfahem A., Zgheel F., Ahmed M.O. 2013 Antibacterial In-Vitro Activities of Selected Medicinal Plants against Methicillin-Resistant Staphylococcus Aureus from Libyan Environment - J. Environ. Anal. Toxicol. 3: 194.

Al Laham S.A., Al Fadel F.M. 2014 - Antibacterial activity of various plants extracts against antibiotic-resistant Aeromonas hydrophyla - Jundishapur J. Microbiol. 7: 1-7.

Ali M., Chaudhary N. 2011 - Ficus hispida Linn.: A review of its pharmacognostic and ethnomedicinal properties Pharmacogn. Rev. 5: 96-102.

Atindehou K.K., Koné M., Terreaux C., Traore D., Hostettmann K., Dosso M. 2002 - Evaluation of the antimicrobial potential of medicinal plants from the Ivory Coast - Phytother. Res. 16: 497-502.

Badgujar S.B., Patel V.V., Bandivdekar A.H., Mahajan R.T. 2014 - Traditional uses, phytochemistry, and pharmacology of Ficus carica: a review - Pharm. Biol. 52: 1487-1503.

Barnes A.C. 2011 - Enteric Redmouth Disease (ERM) (Yersinia ruckeri) - In: Fish Diseases and Disorders, Volume 3: Viral, Bacterial and Fungal Infections (Eds) P.T.K. Woo, D.W. Bruno, MPG Books Group, UK.

Bauer A.W., Kirby W.M., Sherris J.C., Turck M. 1966 - Antibiotic susceptibility testing by a standardized single disk method - Am. J. Clin. Pathol. 45: 493-496.

Birinci Yıldırım A., Turker H. 2018 - Antibacterial activity of some aromatic plant essential oils against fish pathogenic bacteria - LimnoFish. 4: 67-74.

Borges A., Abreu A.C., Dias C., Saavedra M.J., Borges F., Simőes M. 2016 - New perspectives on the use of phytochemicals as an emergent strategy to control bacterial infections including biofilms - Molecules 21: 877.

Bortolus A. 2008 - Error cascades in the biological sciences: the unwanted consequences of using bad taxonomy in ecology - Ambio 37: 114-118.

Brummit R.K., Powell C.E.P. 1992 - Authors of plant names. A list of authors of scientific names of plants, with recommended standard forms of their names, including abbreviations - Royal Botanic Garden Kew, London, 732 p.

Bunawan H., Amin N.M., Bunawan S.N., Baharum S.N., Mohd Noor N. 2014 - Ficus deltoidea Jack: A Review on Its Phytochemical and Pharmacological Importance Evid. Based Complement. Alternat. Med. 2014: 902734.

Caruso G. 2016 - Antibiotic Resistance in Fish Farming Environments: A Global Concern - Journal of FisheriesSciences.com, 10: 9-13.

Cheng J.-Y., Guan, M., Zhu, J.-L., Wang, C.-T., Su L., Zhang X.-J. 2014 - Facile and material-independent fabrication of poly(luteolin) coatings and their unimpaired antibacterial activity against Staphylococcus aureus after steam sterilization treatments - Polym. Chem. 5: 4211-4214.

Cibrian-Jaramillo A., Hird A., Oleas N., Ma H., Meerow A.W., Francisco-Ortega J., Griffith M.P. 2013 - What is the conservation value of a plant in a botanic garden? Using indicators to improve management of ex-situ collections Bot. Rev. 79: 559-577.

Cowan M.M. 1999 - Plant products as antimicrobial agents Clin. Microbiol. Rev. 12: 564-582.

Cushnie T.P., Lamb A.J. 2005 - Antimicrobial activity of flavonoids - Int. J. Antimicrob. Agents 26: 343-356.

Daglia M. 2012 - Polyphenols as antimicrobial agents - Curr. Opin. Biotechnol. 23: 174-181.

Dangarembizi R., Erlwanger K.H., Moyo D., Chivandi E. 2012 - Phytochemistry, pharmacology and ethnomedicinal uses of Ficus thonningii (Blume Moraceae): a review Afr. J. Tradit. Complement. Altern. Med. 10: 203-212.

Ewing W.H., Ross A.J., Brenner D.J., Fanning G.R. 1978 Yersinia ruckeri sp. nov. Redmouth (RM) Bacterium - Int. J. Syst. Bacteriol. 28: 37-44.

Ghosh B., Nguyen T.D., Crosbie P.B., Nowak B.F., Bridle A.R. 2016 - Oral vaccination of first-feeding Atlantic salmon, Salmo salar L., confers greater protection against yersiniosis than immersion vaccination - Vaccine 34: 599-608.

Khameneh B., Iranshahy M., Ghandadi M., Ghoochi Atashbeyk D., Fazly Bazzaz B.S., Iranshahi M. 2015 Investigation of the antibacterial activity and efflux pump inhibitory effect of co-loaded piperine and gentamicin nanoliposomes in methicillin-resistant Staphylococcus aureus - Drug Dev. Ind. Pharm. 41: 989-994.

Kocwowa E. 1981 - Exercises in general microbiology Państwowe Wydawnictwo Naukowe, Warszawa: 78-85 (in Polish).

Kumar G., Menanteau-Ledouble S., Saleh M., El-Matbouli M. 2015 - Yersinia ruckeri, the causative agent of enteric redmouth disease in fish - Vet. Res. 46: 103.

Lansky E.P., Paavilainen H.M. 2011 - Figs: the genus Ficus In: Traditional herbal medicines for modern times, Vol. 9 (ed.) R. Hardman, CRC Press, Boca Raton: 1-357.

Madhuri S., Mandloi A.K., Pandey Govind, Sahni Y.P. 2012 Antimicrobial activity of some medicinal plants against fish pathogens - Int. Res. J. Pharm. 3: 28-30.

Majumder P., Paridhavi M. 2013 - An ethno-phytochemical and pharmacological review on novel Indian medicinal plants used in herbal formulations - Int. J. Pharm. Pharm. Sci. 5: 74-83.

Mousa O., Vuorela P., Kiviranta J., Wahab S.A., Hiltunen R., Vuorela H. 1994 - Bioactivity of certain Egyptian Ficus species - J. Ethnopharmacol. 41: 71-76.

Nabavi S.M., Marchese A., Izadi M., Curti V., Daglia M., Nabavi S.F. 2015 - Plants belonging to the genus Thymus 
as antibacterial agents: from farm to pharmacy - Food Chem. 173: 339-347.

Nair R., Chanda S. 2006 - Activity of some medicinal plants against certain pathogenic bacterial strains - Indian J. Pharmacol. 38: 142-144.

Nair R., Chanda S.V. 2007 - Antibacterial activities of some medicinal plants of the western region of India - Turk. J. Biol. 31: 231-236.

Okoth D.A., Chenia H.Y., Koorbanally N.A. 2013 - Antibacterial and antioxidant activities of flavonoids from Lannea alata (Engl.) Engl. (Anacardiaceae) - Phytochem. Lett. 6: 476-481.

Ormsby M.J., Caws T., Burchmore R., Wallis T., Verner-Jeffreys D.W., Davies R.L. 2016 - Yersinia ruckeri isolates recovered from diseased Atlantic salmon (Salmo salar) in Scotland are more diverse than those from rainbow trout (Oncorhynchus mykiss) and represent distinct sub-populations - Appl. Environ. Microbiol. 82: 5785-5794.

Padmanabhan P., Jangle S.N. 2012 - Evaluation of in-vitro anti-inflammatory activity of herbal preparation, a combination of four medicinal plants - Int. J. App. Basic Med. Res. 2: 109-116.

Pękala A., Antychowicz J. 2010 - Yersiniosis of salmonids epizootiology of the disease and methods of its elimination - Med. Weter. 66: 374-377 (in Polish).

Reverter M., Bontemps N., Lecchini D., Banaigs B., Sasal P. 2014 - Use of plant extracts in fish aquaculture as an alternative to chemotherapy: Current status and future perspectives - Aquaculture 433: 50-61.

Romero J., Feijoó C.G., Navarrete P. 2012 - Antibiotics in Aquaculture-Use, Abuse, and Alternatives - In: Health and Environment in Aquaculture (Eds) E.D. Carvalho, G.S. David, R.J. Silva, InTech Open 6: 159-198.

Salem M.Z.M., Salem A.Z.M., Camacho L.M., Ali H.M. 2013 Antimicrobial activities and phytochemical composition of extracts of Ficus species: An overview - Afr. J. Microbiol. Res. 7: 4207-4219.

Sosnovskiy Y.V. 2014 - Taksonomic diversity of Ficus L. (Moraceae Link) in collections of botanical gardens in Ukraine - Biolohichni studiyi 8(2): 197-216 (in Ukrainian).
Tkachenko H., Buyun L., Terech-Majewska E., Osadowski Z. 2016 - Antibacterial activity of ethanolic leaf extracts obtained from various Ficus species (Moraceae) against the fish pathogen, Citrobacter freundii - Balt. Coast. Zone 20: 117-136.

Tkachenko H., Buyun L., Terech-Majewska E., Osadowski Z. 2016 - In vitro antimicrobial activity of ethanolic extracts obtained from Ficus spp. leaves against the fish pathogen Aeromonas hydrophila - Arch. Pol. Fish. 24: 219-230.

Tkachenko H., Buyun L., Terech-Majewska E., Osadowski Z., Honcharenko V., Prokopiv A. 2016 - Anti-Pseudomonas fluorescens efficacy of ethanolic extracts derived from the leaves of various Ficus species (Moraceae) - Słupskie Prace Biologiczne 13: 295-316.

Tkachenko H., Buyun L., Terech-Majewska E., Osadowski Z., Sosnovskyi Y., Honcharenko V., Prokopiv A. 2016 - The antimicrobial activity of some ethanolic extracts obtained from Ficus spp. leaves against Aeromonas hydrophila Trudy VNIRO 162: 172-183.

Tkachenko H., Buyun L., Terech-Majewska E., Osadowski Z., Sosnovskyi Y., Honcharenko V., Prokopiv A. 2016 - In vitro antibacterial efficacy of various ethanolic extracts obtained from Ficus spp. leaves against the fish pathogen, Pseudomonas fluorescens - In: Globalisation and regional environment protection. Technique, technology, ecology (Eds) T. Noch, W. Mikołajczewska, A. Wesołowska. Gdańsk, Gdańsk High School Publ.: 265-286.

Turker H., Yıldırım A.B. 2015 - Screening for antibacterial activity of some Turkish plants against fish pathogens: a possible alternative in the treatment of bacterial infections - Biotechnol. Biotechnol. Equip. 29: 281-288.

Van Hai N. 2015 - The use of medicinal plants as immunostimulants in aquaculture: A review Aquaculture 446: 88-96.

Vital P.G., Velasco R.N.Jr., Demigillo J.M., Rivera W.L. 2010 - Antimicrobial activity, cytotoxicity and phytochemical screening of Ficus septica Burm and Sterculia foetida L. leaf extracts - J. Med. Plants Res. 4: 58-63.

Whitman K.A., MacNair N.G. 2004 - Finfish and shellfish bacteriology manual: techniques and procedures Blackwell Publishing Company, Iowa, USA.

Yang C., Chowdhury M.A., Huo Y., Gong J. 2015 Phytogenic compounds as alternatives to in-feed antibiotics: potentials and challenges in application - Pathogens 4: 137-156. 